\title{
Ratio of digestible lysine to arginine in Japanese laying quails
}

\author{
Relação de lisina $x$ arginina digestível para codornas \\ japonesas em postura
}

\author{
Thamírys Vianelli Maurício ${ }^{1 *}$; José Geraldo de Vargas Junior ${ }^{2}$; \\ Matheus Faria de Souza ${ }^{3}$; Bibliana da Costa Ferrreira ${ }^{4}$; \\ Ricardo Vianna Nunes ${ }^{5}$; Flávio Medeiros Vieites ${ }^{6}$
}

\begin{abstract}
The objective of this study was to evaluate the existence of an interaction between lysine and arginine, and to determine their optimal ratio in the diets of Japanese laying quails. We used 480 quails with an initial mean weight of $180 \mathrm{~g}$ at 140 days of age. The quails were distributed in the experimental units in a completely randomized $(3 \times 2)$ factorial design, with three levels of digestible lysine $(1.083$, $1.183,1.283 \%)$ and two levels of digestible arginine $(1.472$ and $1.580 \%)$. There were six treatments, with 10 replicates each, for a total of 60 experimental units. Rations, leftovers, and dead animals were weighed in order to calculate and adjust performance parameters. The variables analyzed were: daily diet consumption (DDC), laying rate (LR), average egg weight (AEW), egg mass (EM), feed conversion per egg mass and dozen eggs (FCEM and FCDE, respectively), weights of yolk, eggshell, and albumen (YW, ESW, and AW, respectively), relative yolk, eggshell, and albumen weights (RYW, RESW, and RAW, respectively), Haugh unit (HU), and marketable egg percentage (ME). There was no interaction $(\mathrm{P}>0.05)$ between the levels of digestible lysine and arginine on the parameters analyzed; independently, these parameters were not affected by lysine and arginine levels. In conclusion, the optimal ratio of lysine and arginine in the diet of laying quails was 1.36: 1.00, which was the lowest used in the present study.
\end{abstract}

Key words: Amino acids. Poultry. Amino acid interaction.

\section{Resumo}

Objetivou-se avaliar a existência de interação aminoacídica entre lisina e arginina, assim como, determinar a melhor relação entre eles em dietas para codornas japonesas em postura. Foram utilizadas 480 codornas com peso médio inicial de $180 \mathrm{~g}$ aos 140 dias de idade. As codornas foram distribuídas nas unidades experimentais em delineamento inteiramente casualizado esquema fatorial ( $3 \times 2)$ no qual foram utilizados três níveis de lisina digestível $(1,083 ; 1,183 ; 1,283 \%)$ e dois níveis de arginina digestível $(1,472$ e $1,580 \%)$. Totalizando seis tratamentos com dez repetições cada, num total de 60 unidades experimentais. As rações, as sobras e os animais mortos foram pesadas a fim de calcular e ajustar os parâmetros de desempenho. As variáveis analisadas foram: consumo de ração diário (CRD), taxa de postura (TP), peso médio dos ovos (PO), massa dos ovos (MO), conversão alimentar por massa de ovos

${ }^{1}$ Prof ${ }^{a}$, Centro Universitário do Espírito Santo, UNESC, Colatina, ES, Brasil. E-mail: thavianelli@gmail.com

2 Prof., Centro de Ciências Agrárias da Universidade Federal do Espírito Santo, CCA, UFES, Alegre, ES, Brasil. Bolsista de Produtividade em Pesquisa/FAPES. E-mail: josegeraldovargas@yahoo.com.br

3 Zootecnista, Dr., Pesquisador, Colatina, ES, Brasil. E-mail: matheusfari@yahoo.com.br

${ }^{4}$ Zootecnista, M.e, Pesquisadora, Alegre, ES, Brasil. E-mail: biblianadcf@hotmail.com

5 Prof., Universidade Estadual do Oeste do Paraná, UNIOESTE, Marechal Cândido Rondon, PR, Brasil. E-mail: nunesrv@hotmail. com

${ }^{6}$ Prof., Universidade Federal de Juiz de Fora, UFJF, Juiz de Fora, MG, Brasil. E-mail: fmvieites@yahoo.com.br

* Author for correspondence 
e por dúzia de ovos (CAMO e CADO), pesos da gema, casca e albúmen (PG, PC e PA), pesos relativos da gema, da casca e do albúmen (PRG, PRC e PRA), além da unidade Haugh (UH) e percentual de ovos comercializáveis $(\mathrm{OC})$. Não houve interação $(\mathrm{P}>0,05)$ entre os níveis de lisina e arginina digestível sobre os parâmetros em análise, de maneira independente os níveis de lisina e de arginina também não afetaram os parâmetros em análise. Concluiu-se que a melhor relação de lisina e arginina para codornas em fase de postura foi a menor em estudo: 1,36:1,00.

Palavras-chave: Aminoácidos. Aves. Interação aminoacídica.

\section{Introduction}

Brazil is currently the world's second largest producer of quail eggs from the species Coturnix coturnix japonica (Japanese quail) (SILVA et al., 2012). In recent years, substantial development has been observed in this activity, with readjustment of new techniques and production technologies. Thus, subsistence activity is now a highly technical activity (PASTORE et al., 2012). This is demonstrated by the increased number of quails, with 20.34 million animals in 2014, representing an increase of $11.9 \%$ from 2013 (IBGE, 2014).

Feeding affects the production costs of quails, from the base (genetic improvement) to the top of the production chain (slaughterhouses and refrigerators). Considering that quail diets contain more protein than chicken and laying hen diets, the cost of feeding quails per unit of meat or egg product is supposedly higher. However, as knowledge on nutrition evolves, diets are formulated with minimal cost and maximum profit (SILVA et al., 2012).

Lysine is the second most limiting amino acid in quail diets, and the high interest in studies investigating this amino acid is justified by its low supplementation costs and its effect on quail performance. Lysine is involved in corporal protein deposition and carnitine synthesis, which transports fatty acids to mitochondria for $\alpha$-oxidation. However, excess levels of lysine can lead to metabolic damage due to antagonism with other amino acids, such as arginine, as they compete for the same absorption sites (PINTO et al., 2003).

The essential amino acid arginine has special importance in quail diets, and is considered one of the most limiting amino acids in corn and soybean diets for these animals. In addition, because quails do not have a functional urea cycle, these animals have a higher arginine requirement than mammals (EDMONDS et al., 1985).

Therefore, this study aimed to investigate interactions between lysine and arginine, and to determine the optimal ratio of these amino acids in diets for Japanese laying quails.

\section{Material and Methods}

The experiment was performed in the poultry sector of the Federal Institute of Espírito Santo (IFES), in the municipality of Alegre - ES, located in Rive - Alegre district (latitude of $20^{\circ} 45^{\prime} 49^{\prime \prime}$ and longitude of $\left.41^{\circ} 31^{\prime} 57^{\prime \prime}\right)$, at an altitude of $150 \mathrm{~m}$, with a sub-humid tropical climate and annual rainfall of approximately $1200 \mathrm{~mm}$.

The experiment was supported by the Ethics Committee on Animal Use (CEUA) of the Health Sciences Center of the Federal University of Espírito Santo (CCS-UFES), protocol no. 65/2015, performed in accordance with the current norms for the use of animals for experimentation.

A brick shed was used, with east-west orientation, ceiling height of $3.5 \mathrm{~m}$, covered with asbestos roof tiles, and with open sides with screens and curtains. Egg quality variables were analyzed at the Laboratory of Bromatology and Animal Nutrition of the Department of Animal Science, located in the central building of the Center of Agricultural Sciences of the Federal University of Espírito Santo (CCA - UFES), in Alegre-ES.

The cages used to house the quails were made from galvanized wire, arranged in the form of stairs, 
with three levels of steps containing a front feeder, nipple-type drinker on the opposite side, and an egg trimmer. The dimensions of the cages were $1.00 \times$ $0.33 \times 0.15 \mathrm{~m}$ (length $\times$ width $\times$ height $)$, subdivided into three units, each $0.33-\mathrm{m}$ long.

In total, 480 female Japanese quail (Coturnix japonica), with an average initial weight of 180.0 $\mathrm{g}$ at 140 days of age were used in 60 experimental units, with eight animals per unit. Water and diet were provided to the animals with no restrictions during the experimental period, and the diet was divided into two daily meals (at 08:00 and 17:00) to avoid any waste. The experimental period was between March and June 2014, with a total of 84 experimental days, subdivided into four periods of 21 days.

The quails were weighed before the experimental period and distributed by weight to control egg production for a period of 14 days. Afterwards, quails were redistributed according to laying, thus initiating the experimental period.

The diets were formulated with corn and soybean, supplemented with L-arginine and L-lysine $\mathrm{HCl}$ using a factorial scheme $(3 \times 2)$ composed of three levels of digestible lysine $(1.083 ; 1.183 ; 1.283 \%)$ and two levels of digestible arginine (1.472 and $1.580 \%)$. Therefore, the trial included six treatments (Table 1), 10 replicates, and eight animals per experimental unit, for a total of 60 experimental units.

The maximum/minimum temperatures and relative humidity in the shed were measured every hour, on all experimental days, using a data logger. The light program was based on a 16 -h photoperiod and natural light was supplemented with artificial light, which was controlled automatically using a timer.

The performance variables were: laying rate (\%), average egg weight (g), egg mass (g of egg/ animal/day), daily intake of food (g/animal/day), food conversion ( $g$ of diet/g of egg; $g$ of diet/dozens of eggs), and weight variation (g). In addition, the following egg quality variables were analyzed: absolute weight $(\mathrm{g})$ and relative weight $(\%)$ of the yolk, eggshell and albumen, Haugh unit, and percentage of marketable eggs (\%).

Eggs were collected daily at 08:00 and egg production was determined as \%/animal. To calculate egg mass, the production of collected eggs/animal/day was multiplied by the average egg weight.

To determine the average egg weight, egg mass, food conversion ( $\mathrm{g}$ of diet/g of egg), and egg quality parameters (absolute and relative weight of yolk, eggshell, and albumen, and Haugh unit), five eggs/ experimental unit/day were collected during the final 3 days of the second and fourth experimental periods, with a total of 15 eggs/experimental unit/ period evaluated. These samples were labelled and sent to the laboratory to determine egg weight (semianalytical balance, with a precision of $0.01 \mathrm{~g}$ ) and to measure the height of the thick albumen, using a digital caliper with an attached tripod mount.

After weighing, six eggs from the same experimental unit were collected and three were used to determine the Haugh unit (by breaking the egg onto a flat surface, taking care not to break the internal structures of the egg, to determine the height of the thick albumen). Subsequently, the eggshell and yolk of the remaining three eggs were separated.

After washing and labelling, the eggshells were dried in an oven at $65^{\circ} \mathrm{C}$ for $24 \mathrm{~h}$ and then weighed. After these procedures were performed, and whole eggs and egg yolks were weighed, the average weight of the albumen was calculated by subtracting the average weight of the egg yolks and the eggshells from the average weight of the whole eggs. 
Table 1. Composition of the diets.

\begin{tabular}{|c|c|c|c|c|c|c|}
\hline \multirow{4}{*}{$\begin{array}{l}\text { Ingredients (centesimal } \\
\text { composition) }\end{array}$} & \multicolumn{6}{|c|}{ Levels of digestible arginine } \\
\hline & \multicolumn{3}{|c|}{1,472} & \multicolumn{3}{|c|}{1,580} \\
\hline & \multicolumn{3}{|c|}{ Lysine Levels } & \multicolumn{3}{|c|}{ Lysine Levels } \\
\hline & 1,083 & 1,183 & 1,283 & 1,083 & 1,183 & h1,283 \\
\hline Corn & 54,468 & 54,112 & 53,780 & 54,335 & 53,990 & 53,780 \\
\hline Soy Bran 45 & 25,567 & 25,787 & 25,872 & 25,576 & 25,799 & 25,872 \\
\hline Limestone & 7,003 & 7,003 & 7,003 & 7,003 & 7,003 & 7,003 \\
\hline Far.Carne Bones 44 & 4,030 & 4,025 & 4,026 & 4,031 & 4,026 & 4,026 \\
\hline Wheat bran & 3,000 & 3,000 & 3,000 & 3,000 & 3,000 & 3,000 \\
\hline Far. Corn Gluten 60 & 2,000 & 2,000 & 2,000 & 2,000 & 2,000 & 2,000 \\
\hline Soy oil & 1,497 & 1,529 & 1,543 & 1,510 & 1,529 & 1,542 \\
\hline CL Hill 60 & 1,000 & 1,000 & 1,000 & 1,000 & 1,000 & 1,000 \\
\hline Common salt & 0,269 & 0,270 & 0,269 & 0,269 & 0,270 & 0,270 \\
\hline L-Arginine & 0,308 & 0,302 & 0,410 & 0,417 & 0,411 & 0,410 \\
\hline DL-Methionine & 0,361 & 0,360 & 0,360 & 0,362 & 0,360 & 0,360 \\
\hline L-Lysine $\mathrm{HCl}$ & 0,280 & 0,402 & 0,528 & 0,280 & 0,402 & 0,528 \\
\hline L-Tryptophan & 0,034 & 0,033 & 0,032 & 0,034 & 0,033 & 0,032 \\
\hline L-Valine & 0,004 & 0,001 & 0,001 & 0,004 & 0,001 & 0,001 \\
\hline L-Threonine & 0,009 & 0,006 & 0,006 & 0,009 & 0,006 & 0,006 \\
\hline Supl. Min. Aves ${ }^{1}$ & 0,050 & 0,050 & 0,050 & 0,050 & 0,050 & 0,050 \\
\hline Supl. Vitam. Birds & 0,100 & 0,100 & 0,100 & 0,100 & 0,100 & 0,100 \\
\hline Developer Cresc ${ }^{33}$ & 0,010 & 0,010 & 0,010 & 0,010 & 0,010 & 0,010 \\
\hline Antioxidant4 & 0,010 & 0,010 & 0,010 & 0,010 & 0,010 & 0,010 \\
\hline Total & 100,00 & 100,00 & 100,00 & 100,00 & 100,00 & 100,00 \\
\hline \multicolumn{7}{|c|}{ Composition (g/ kg) } \\
\hline Metab energy (Kcal / kg) & 2800 & 2800 & 2800 & 2800 & 2800 & 2800 \\
\hline Crude protein & 202,020 & 203,820 & 205,130 & 201,960 & 203,630 & 205,130 \\
\hline Calcium & 30,990 & 30,990 & 30,990 & 30,990 & 30,990 & 30,990 \\
\hline Sodium & 1,550 & 1,550 & 1,550 & 1,550 & 1,550 & 1,550 \\
\hline Available P & 3,230 & 3,230 & 3,230 & 3,230 & 3,250 & 3,230 \\
\hline Linoleic acid & 21,480 & 21,600 & 21,620 & 21,520 & 21,600 & 21,620 \\
\hline Arginine dig. & 14,720 & 14,720 & 14,720 & 15,800 & 15,800 & 15,800 \\
\hline Lysine dig. & 10,830 & 11,830 & 12,830 & 10,830 & 11,830 & 12,830 \\
\hline Met. + Cys. dig. & 8,880 & 8,880 & 8,880 & 8,880 & 8,880 & 8,880 \\
\hline Met. dig. & 6,260 & 6,260 & 6,250 & 6,260 & 6,260 & 6,250 \\
\hline Tryptophan dig. & 2,270 & 2,270 & 2,270 & 2,270 & 2,270 & 2,270 \\
\hline Threonine dig. & 6,490 & 6,490 & 6,490 & 6,490 & 6,490 & 6,490 \\
\hline Valine dig. & 8,120 & 8,120 & 8,120 & 8,120 & 8,120 & 8,120 \\
\hline Isoleucine dig. & 7,160 & 7,200 & 7,200 & 7,160 & 7,200 & 7,200 \\
\hline Leucine dig. & 16,120 & 16,150 & 16,150 & 16,110 & 16,150 & 16,150 \\
\hline Phenylalanine dig. & 8,740 & 8,780 & 8,780 & 8,740 & 8,780 & 8,780 \\
\hline Phenyl + Tyr. dig. & 14,980 & 15,040 & 15,050 & 14,980 & 15,040 & 15,050 \\
\hline
\end{tabular}

${ }^{1}$ Mineral Supplement (per kg of product): $\mathrm{Cu}-6 \mathrm{~g} ; \mathrm{Fe}-30 \mathrm{~g} ; \mathrm{I}-400 \mathrm{mg} ; \mathrm{Mn}=50 \mathrm{~g} ; \mathrm{Se}-180 \mathrm{mg} ; \mathrm{Zn}=40 \mathrm{~g} .{ }^{2}$ Vitamin Supplement (per kg of product): Vitamin A - 12,000,000 IU; vitamin D3 - 2,000,000 IU; vitamin K3 - 1.800mg; vitamin B1 - 1,500mg; vitamin B12 - 12,000mcg; vitamin B2 - 5,000mg; vitamin B6-2800mg; vitamin E - 15,000 IU; niacin - 35g; biotin - 25mg; pantothenic acid-12g; folic acid-750mg. ${ }^{3}$ Bacitracin of Zinc. 4-Hydroxy-toluene. 
To determine the Haugh unit, the equation $\mathrm{HU}=$ $100 \times \log \left(\mathrm{H}=1.7 \times \mathrm{W}^{0.37}+7.6\right)$ was used, where $\mathrm{H}$ is the height of the thick albumen and $\mathrm{W}$ is the weight of the whole egg (BAPTISTA, 2002).

Diet consumption was calculated at the end of the experimental period by subtracting the leftovers from the diet originally provided. Dead animals and leftovers were weighed on the day of death, to correct the estimated diet consumption, laying, and food conversion (SAKOMURA; ROSTAGNO, 2007).

Food conversion was determined using the relationship between the daily food intake and the average egg production in grams (conversion in $\mathrm{g} / \mathrm{g}$ ), as well as the average daily production in dozens of eggs (conversion in $\mathrm{kg} / \mathrm{dz}$ ). The percentage of marketable eggs (\%) was calculated by dividing the number of intact eggs (without cracks, fractures, or "soft shells") by the total number of collected eggs, multiplied by 100 .
The statistical model used was: Yijk $=\mu+\alpha \mathrm{i}+\beta \mathrm{j}$ $+\alpha \beta \mathrm{ij}+$ eijk, where $\mu=$ general average; $\alpha=$ effect of lysine level; $\beta=$ effect of arginine level; $\alpha \beta=$ effect of the interaction between lysine and arginine levels, e $=$ random error.

Performance and egg quality variables were analyzed using the procedures for variance analysis, F-test, and SNK regression, when relevant, through the Statistical and Genetic Analysis System (SAEG), developed at the Federal University of Viçosa (UFV, 2007), version 9.1. For all statistical procedures, the following probability value was considered: $0.05 \%$.

\section{Results and Discussion}

No interaction $(\mathrm{P}>0.05)$ was observed between the levels of digestible lysine and arginine used in the diets of the animals and the performance parameters of daily diet consumption (DDC), laying rate (LR), average egg weight (AEW), egg mass (EM), and food conversion per mass and per dozen eggs (FCEM and FCDE, respectively) (Table 2).

Table 2. Performance of Japanese quails fed with different lysine levels, whether or not the relationship with arginine was maintained.

\begin{tabular}{|c|c|c|c|c|c|c|c|c|c|}
\hline \multirow{2}{*}{$\begin{array}{l}\text { Parameters }{ }^{1} \\
\text { Performance }\end{array}$} & \multicolumn{3}{|c|}{ Lysine Levels (\%) } & \multicolumn{2}{|c|}{ Arginine Levels (\%) } & \multicolumn{3}{|c|}{ P-Value ${ }^{2}$} & \multirow{2}{*}{$\begin{array}{l}\mathrm{CV}^{3} \\
(\%)\end{array}$} \\
\hline & 1,083 & 1,183 & 1,283 & 1,472 & 1,58 & Lis & Arg & LisxArg & \\
\hline $\mathrm{DDC}(\mathrm{g})$ & 25,36 & 25,49 & 25,45 & 25,62 & 25,24 & 0,979 & 0,492 & 0,557 & 8,35 \\
\hline LR (\%) & 91,87 & 93,41 & 92,28 & 91,99 & 93,04 & 0,572 & 0,397 & 0,169 & 5,14 \\
\hline AEW (g) & 11,85 & 11,86 & 11,81 & 11,91 & 11,77 & 0,879 & 0,142 & 0,818 & 3,04 \\
\hline EM (g/ave/dia) & 10,88 & 11,08 & 10,90 & 10,96 & 10,95 & 0,574 & 1,000 & 0,305 & 6,10 \\
\hline FCEM $(\mathrm{g} / \mathrm{g})$ & 2,55 & 2,58 & 2,50 & 2,56 & 2,53 & 0,709 & 0,662 & 0,268 & 11,90 \\
\hline FCDE (g/dz.) & 0,333 & 0,328 & 0,331 & 0,335 & 0,326 & 0,886 & 0,246 & 0,157 & 9,64 \\
\hline
\end{tabular}

${ }^{1} \mathrm{DDC}=$ daily diet consuption, $\mathrm{LR}=$ laying rate, $\mathrm{AEW}=$ average egg weight, $\mathrm{EM}=$ egg mass, $\mathrm{FCEM}=$ feed conversion per egg mass and FCDE $=$ feed conversion per dozen eggs. ${ }^{2}$ Values above 0.05 are not considered significant. ${ }^{3} \mathrm{CV}=$ coefficient of variation.

These results are similar to those reported by Chamruspollert et al. (2002), who observed no interaction between lysine and arginine in chick studies investigating digestible arginine, methionine, and lysine ratios. However, the results were not consistent with those reported by Lima and Silva (2007), who used the same amino acids as the present study with laying hens and found that the arginine $\times$ lysine interaction affected egg production, weight, and food conversion per egg mass.

The lack of an interaction in the present study can be explained by the age of the animals used in the experiments. As a greater demand for essential 
amino acids is observed, with a consequent increase in amino acid imbalances, during the growth stages of these animals compared with older quails.

The levels of digestible lysine did not influence $(\mathrm{P}>0.05)$ food consumption (DDC) by the animals. This can be confirmed by the results of several studies, in which there was no observable effect of lysine levels on this parameter (RIBEIRO et al., 2011; CUPERTINO et al., 2009). Conversely, Rocha et al. (2009) and others observed a linear decrease in lysine on food intake by laying hens.

The levels of digestible arginine did not influence $(\mathrm{P}>0.05)$ the DDC of the animals. These results are similar to those reported by Araújo et al. (2005) in a study using six digestible lysine:arginine ratios (718:716; 790:716; 718:644; 790:644; $718: 788$, and $790: 788 \mathrm{mg}$ of lysine:arginine $/ \mathrm{kg}$ of diet, respectively) in Lohmann LSL at 40 weeks of age, and observed no differences in this parameter. Conversely, Carvalho et al. (2006) showed a quadratic effect of digestible arginine levels on the DDC of laying hens.

The range of digestible lysine levels used in the study may not be sufficient to act on the biochemical mechanism underlying the anorexic effect, which may explain the lack of effect on voluntary food intake (HARPER; ROGERS, 1965). Similar to dietary energy levels, dietary lysine levels also regulate daily food intake in Japanese laying quails (BARRETO et al., 2006).

According to Goulart (1997), excess circulating amino acids in the blood can lead to decreased food consumption by the animals, which may explain a lower average consumption when compared with the level recommended by Rostagno et al. (2011), at $26.22 \mathrm{~g}$.

There was no variation $(\mathrm{P}>0.05)$ in laying rate (LR) with increased levels of digestible lysine in the diet. This is consistent with the findings of Souza et al. (2006) who observed no effect of the treatments on egg production when analyzing digestible lysine and arginine levels for laying hens. On the contrary, Cupertino et al. (2009) observed that egg production was influenced, in a quadratic way, by dietary digestible lysine levels.

There was no variation $(\mathrm{P}>0.05)$ in $L R$ at different levels of digestible arginine used in the present experiment. In a similar study, Lima and Silva (2007) reported no differences in egg production for laying hens at 44 weeks of age. Conversely, Araújo et al. (2005) observed higher egg production with a digestible lysine:arginine ratio of 718:716 mg, and lower production with ratios of 790:716 and 718:644 $\mathrm{mg}$.

It should be noted that the quails used in the present study were past their laying peak, and were in a plateau stage; therefore, weight gain was slowing and stabilizing. This allows most of the lysine consumed to be used for protein deposition, explaining the high average egg production obtained (SILVA et al., 2005). The fact that the lysine levels vary with arginine levels considered high for this animal category explains the lack of an effect with the levels used on this parameter.

No effect $(\mathrm{P}>0.05)$ was observed at different levels of digestible lysine on the average egg weight (AEW). These results are consistent with those of Costa et al. (2008), who found no significant difference when analyzing levels of digestible lysine (0.88 to $1.20 \%)$ for Japanese laying quails. Conversely, Schmidt et al. (2008) found a quadratic effect for this parameter in studies using different levels of digestible lysine in laying quails.

The levels of digestible arginine had no effect $(\mathrm{P}>0.05)$ on the average egg weight (AEW) of the experimental animals. This is consistent with the findings of Lima et al. (2005), who reported no differences for this parameter in laying hens at 44 weeks of age. However, Araújo et al. (2005) obtained a lower egg weight (AEW) in Lohmann LSL laying hens using 790:716 digestible lysine:arginine/kg of diet, compared to other treatments in Lohmann Brown and Lohmann LSL animals at 40 weeks of age. 
The results of the present study are consistent with those of Singh and Narayan (2002), who reported an increase from 9 to $12 \mathrm{~g}$ between the beginning and the end of production. Murakami and Ariki (1998) reported an average of $10.39 \mathrm{~g}$ for eggs produced between the 36th and 44th week of production. Thus, the values obtained in that study were higher than those cited in previous studies. Britton (1976) analyzed a decline in the internal and external quality of eggs with the age of animals, and reported a significant increase in the egg weight at the end of laying, which is the case of that study.

Although quail eggs are generally marketed per unit, rather than by weight, the use of low levels of protein without amino acid supplementation may compromise the size of the eggs, with sizes outside of the standard This did not occur in the present experiment, using a PB level of $20 \%$, which despite being lower than the level indicated by Rostagno et al. (2011) (22-23\%), is consistent with the recommendations of Silva and Costa (2009).

Similar to weight, the average egg mass (AEM) was not influenced $(\mathrm{P}>0.05)$ by the levels of digestible lysine studied. The results obtained agree with those reported by Jardim Filho et al. (2010), who observed no effect of the digestible lysine levels on egg mass (EM) in Japanese laying quails. In contrast, Cupertino et al. (2009) observed a quadratic effect of lysine levels on this parameter in laying hens.

The levels of digestible arginine analyzed in the present study did not influence $(\mathrm{P}>0.05)$ the average egg mass (EM). These results are similar to those reported by Carvalho et al. (2006) in studies of lysine and arginine in laying hens. However, Sá et al. (2004) observed a quadratic effect for EM of laying hens fed with lysine and arginine.

The discrepancies in these results are probably because of the different ages of the animals, the amino acid levels used, and differences in the animal species used in each experiment. In addition, it should be noted that as egg mass (EM) correlates with laying rate and egg weight indexes, and these parameters were not influenced in the present study, the lack of effect of different lysine and arginine levels on egg mass was expected. According to Llobet et al. (1989), egg mass is an effective method used to evaluate the performance of a batch of laying hens; therefore, considering the average mass found in this study, the animals can be stated to have exhibited remarkable performance.

There were no differences $(\mathrm{P}>0.05)$ between the levels of digestible lysine used in the diets on food conversion per mass and per dozen eggs (FCEM and FCDE, respectively). These results are similar to those reported by Jordão Filho et al. (2006), who found no effect on FCEM in studies with laying hens. However, FCDE presented quadratic behavior $(\mathrm{P} \leq 0.01)$. The requirement for conversion was estimated at $0.90 \%$ lysine, which is equivalent to the consumption of $975 \mathrm{mg} / \mathrm{animal} /$ day during the laying peak, and is close to the $900 \mathrm{mg}$ of total lysine/animal/day recommended by Schutte and Smink (1998).

The different levels of dietary digestible lysine had no effect $(\mathrm{P}>0.05)$ on FCEM and FCDE. However, Araújo et al. (2005) found that the best food conversion ( $\mathrm{kg} /$ dozen) was obtained with the 718:716 and 718:788 ratios of digestible lysine:arginine $/ \mathrm{kg}$, and the worst conversion was obtained with the 718:644 ratio of lysine:arginine. Similar studies by Lima et al. (2005) in laying hens of the same strains aged 44 weeks, also revealed a difference in food conversion ( $\mathrm{kg} /$ dozen), with the 718:788 ratio showing a better conversion compared with the poor results obtained for the ratios with the highest lysine levels, 718:644 and 790:644 digestible lysine and arginine/ $\mathrm{kg}$ of diet.

The different levels of digestible lysine and arginine used in the present study did not influence $(\mathrm{P}>0.05)$ daily diet consumption (DDC), laying rate (LR), or average egg mass (EM) (Table 2); therefore, as these are dependent parameters, no significant variations $(\mathrm{P}>0.05)$ were expected for FCEM and FCDE. 
Internal and external egg quality were not influenced by the lysine and arginine levels used in this study (Table 3). This lack of interaction between lysine and arginine levels on the observed egg quality parameters indicates that these amino acids do not influence each other with respect to the evaluated parameters, at least not under the experimental conditions used in this study. However, similar studies are scarce in the literature, and no studies are available for comparison. Although no effect was observed among the treatments in the present study, lysine acts as a protagonist in protein synthesis, exerting a key role in egg formation and composition. The discrepancy between published data and the results of the present study may be due to the lysine levels analyzed or the age of the experimental animals.

Table 3. Qualitative aspects of quail eggs fed with different levels of digestible lysine, with or without the relation with arginine.

\begin{tabular}{cccccccccc}
\hline Parameters $^{1}$ & \multicolumn{3}{c}{ Lysine Levels (\%) } & \multicolumn{4}{c}{ Arginine Levels (\%) } & \multicolumn{3}{c}{ P-value $^{2}$} & CV $^{3}$ \\
\cline { 2 - 9 } Qualitative & 1,083 & 1,183 & 1,283 & 1,472 & 1,580 & Lys & Arg & Lys x Arg & $(\%)$ \\
\hline YW (g) & 3,84 & 3,97 & 3,93 & 3,92 & 3,90 & 0,066 & 0,686 & 0,225 & 4,69 \\
ESW (g) & 0,94 & 0,94 & 0,96 & 0,95 & 0,94 & 0,596 & 0,625 & 0,274 & 9,18 \\
AW (g) & 7,30 & 7,22 & 7,13 & 7,25 & 7,18 & 0,672 & 0,661 & 0,757 & 8,18 \\
RESW (\%) & 7,96 & 7,93 & 8,19 & 8,02 & 8,03 & 0,529 & 1,000 & 0,214 & 9,69 \\
RAW (\%) & 61,55 & 60,88 & 60,38 & 60.83 & 61,04 & 0,687 & 0,852 & 0,814 & 7,05 \\
RYW (\%) & 32,37 & 33,50 & 33,27 & 32,93 & 33,16 & 0,029 & 0,515 & 0,102 & 4,17 \\
UH & 78,23 & 78,04 & 78,26 & 78,05 & 78,31 & 0,115 & 0,139 & 0,599 & 0,86 \\
ME (\%) & 98,65 & 98,69 & 98,93 & 98,53 & 98,97 & 0,637 & 0,097 & 0,857 & 1,02
\end{tabular}

${ }^{1} \mathrm{YW}=$ yolk weight, ESW = eggshell weight, AW = albumen weight, RESW = relative weight of eggshell, RAW = relative weight of albumen, $\mathrm{RYW}=$ relative yolk weight, $\mathrm{UH}=$ Haugh unit and $\mathrm{ME}=$ marketable egg percentage. ${ }^{2}$ Values above 0.05 were not considered significant. ${ }^{3} \mathrm{CV}=$ coefficient of variation.

Haugh unit (HU) and yolk weight (YW) were not influenced by the level of digestible lysine $(\mathrm{P}>$ $0.05)$ in the diet. This is consistent with the findings of Rocha et al. (2009). In contrast to most of the literature and results presented here, Geraldo et al. (2008) found a lower value for HU in the control diet, $0.683 \%$ of digestible lysine compared with the other levels used $(0.751,0.819,0.877$, and $0.955 \%)$. This may be due to the experimental conditions, and the age or strain of the animals used.

In that study, high values for egg weight (EW) and yolk weight (YW) were observed; this may be explained by the use of experimental animals that were not young. According to Ahn et al. (1997), younger laying hens (lighter eggs) have a lower yolk:white ratio compared with older hens (heavier eggs). Likewise, the internal quality of the egg is inversely related to the age of the animal, which may explain the lower average HU observed.
The lysine levels used in the present experiment had no effect $(\mathrm{P}>0.05)$ on the albumen weight (AW). A similar result was found by Costa et al. (2008) and Sá et al. (2007), who observed no significant variation in this parameter with increased lysine levels. Conversely, Rocha et al. (2009) found a linear reduction $(\mathrm{P}<0.05)$ in albumen as dietary lysine levels increased, and thus, the basal level $(0.545 \%)$ provided the best response.

As the solid components of egg albumen are almost entirely protein, the demand for protein and amino acids is high; thus, a shortage of protein would result in decreased amounts of albumen and reduced egg size. Similarly, this would affect the amount of egg yolk (SCHMIDT et al., 2011), which was not observed in the present study. This supports the hypothesis that the lower level of lysine used was sufficient to maintain a good internal quality of the eggs. 
The level of digestible lysine in the diet had no influence $(\mathrm{P}>0.05)$ on eggshell weight (ESW). Similarly, Costa et. al. (2008) found no changes in the specific gravity of the eggshell because of the lysine levels in the diet. This suggests that the quality of the eggshell is not influenced by dietary supplementation with lysine, as this amino acid does not induce egg growth, which is shown by the lack of an effect with lysine on this parameter. Some authors have argued that egg weight influences eggshell quality (ROLAND, 1976; HAMILTON, 1979). This is because heavier eggs tend to have a poorer eggshell, as the animal is not able to deposit the same amount of calcium required for the egg growth and weight.

The relative yolk weight, relative eggshell weight, and relative albumen weight (RYW, RESW and RAW, respectively) were not affected $(\mathrm{P}>0.05)$ by the lysine levels in the diets. These findings are in agreement with those of Rocha et al. (2009), who found no effect of lysine levels on the percentage of yolk, eggshell, and albumen, concluding that the levels studied did not influence the internal parameters of the eggs. Those results suggest that differences in the levels of digestible lysine in the present study were not sufficient to substantially change the percentage of the internal and external egg components.

No effect $(\mathrm{P}>0.05)$ of lysine levels was observed on the percentage of marketable eggs (ME). The viability of eggs for commercialization is correlated with several factors, such as egg storage environment, temperature, nutrition of the animals, and handling during egg collection. As in this study, no differences were observed between the treatments on the percentage of eggs suitable for commercialization, and the averages obtained were high, it can be inferred that the environmental conditions and the diet (the amino acid levels used and the CP content for the formation of a resistant eggshell), as well as handling, were adequate.
Although no changes were observed in the parameters analyzed in the present study with increased arginine levels, this amino acid is involved in several functions related to reproduction in mammals, including: folliculogenesis, embryogenesis, placental growth and development, mediation of placental blood flow, maintenance of pregnancy and childbirth, and embryonic development (WU et al., 2004). This has been shown in mares, dogs, sheep (WU et al., 2005), swine (WU; MORRIS, 1998), and even in humans. Therefore, although no effect on egg quality parameters was observed in the present study, and literature in quails is scarce, it can be inferred that arginine supplementation has a beneficial effect on these parameters.

\section{Conclusion}

The best digestible lysine $\times$ arginine ratio for the parameters analyzed was 1.36 .

\section{References}

AHN, D. U.; KIM, S. K.; SHU, H. Effect of egg size and strain and age of hen on the solids content of chicken eggs. Poultry Science, Champaign, v. 76, n. 6, p. 914919, 1997. Available at: <https://academic.oup.com/ps/ article/76/6/914/1588580/Effect-of-egg-size-and-strainand-age-of-hens-on>. Accessed at: 10 dec. 2016.

ARAÚJO, D. M.; VILAR, S.; LIMA, M. R.; ARAÚJO, J. A.; JORDÃO FILHO, J.; RIBEIRO, M. L. G. Níveis de lisina e arginina digestível para poedeiras no pico de postura. In: CONFERÊNCIA APINCO DE CIÊNCIA E TECNOLOGIA AVÍCOLAS, 7., 2005, Santos. Anais.. Campinas: FACTA, 2005. p. 136.

BAPTISTA, R. F. Avaliação da qualidade interna de ovos de codorna (Coturnix couturnix japonica) em função da variação de temperatura de armazenamento. 2002. Dissertação (Mestrado em Medicina Veterinária) Universidade Federal Fluminense, Niterói. 
BARRETO, S. L. T.; ARAUJO, M. S. de; UMIGI, R. T.; DONZELE, J. L.; ROCHA, T. C. da; PINHEIRO, S. R. F.; SILVA, R. F. Exigência nutricional de lisina para codornas européias machos de 21 a 49 dias de idade. Revista Brasileira de Zootecnia, Viçosa, MG, v. 35, n. 3, p. 750-753, 2006. Disponível em: <http://www.sbz.org. br/revista/artigos/5019.pdf>. Acesso em: 10 dez. 2016.

BRITTON, W. M. Effect of albumen $\mathrm{pH}$ on yolk mottling. Poultry Science, Champaign, v. 55, n. 4, p. 1330-1335, 1976. Available at: <https://academic.oup.com/ps/ article-abstract/55/4/1330/1536509/Effect-of-AlbumenpH-on-Yolk-Mottling>. Accessed at: 10 dec. 2016.

CARVALHO, F. B.; STRINGHINI, J.; CAFÉ, M. Desempenho de poedeiras alimentadas com diferentes níveis de lisina e arginina digestíveis de 24 a 44 semanas de idade. In: CONFERÊNCIA APINCO DE CIÊNCIA E TECNOLOGIA AVÍCOLAS, 2006, Santos. Anais... Santos: Fundação Apinco de Ciência e Tecnologia Avícolas, 2006. p. 91.

CHAMRUSPOLLERT, M.; PESTI, G. M.; BAKALLI, R. I. Dietary interrelationships among arginine, methionine, and lysine in young broiler chicks. British Journal of Nutrition, Cambridge v. 88, n. 6, p. 655660,2002 . Available at: <https://www.cambridge. org/core/services/aop-cambridge-core/content/view/ S0007114502002404>. Accessed at: 10 dec. 2016.

COSTA, F. G. P.; RODRIGUES, V. P.; GOULART, C. C.; LIMA NETO, R. C.; SOUZA, J. G.; SILVA, J. H. V. Exigências de lisina digestível para codornas japonesas na fase de postura. Revista Brasileira de Zootecnia, Viçosa, MG, v. 37, n. 12, p. 2136-2140, 2008. Disponível em: <https://www.researchgate.net/ profile/Raul Lima Neto2/publication/250040106_Exigencias de lisina digestivel_para_codornas_japonesas_na_fase_de postura/links/543fce170cf21227a11b82c3.pdf $>$. Acesso em: 10 dez. 2016.

CUPERTINO, E. S.; GOMES, P. C.; ALBINO, L. F. T.; DONZELE, J. L.; MELLO, H.; SCHMIDT, M.; CALDERANO, A. A. Exigência nutricional de lisina digestível para galinhas poedeiras de 54 a 70 semanas de idade. Revista Brasileira de Zootecnia, Viçosa, MG, v. 38, n. 3, p. 480-487, 2009. Disponível em: <http:// s3.amazonaws.com/academia.edu.documents/43040523/ Exigncia_nutricional_de_lisina_pdf $>$. Acesso em: 10 dez. $201 \overline{6}$.

EDMONDS, M. S.; PARSONS, C. M.; BAKER, D. H. Limiting amino acids in low-protein cornsoybean meal diets fed to growing chicks. Poultry Science, Champaign, v. 64, n. 8, p. 1519-1526, 1985. Available at: <https://academic.oup.com/ps/articleabstract/64/8/1519/1505885/Limiting-Amino-Acids-inLow-Protein-Corn-Soybean>. Accessed at: 10 dec. 2016.
GERALDO, A.; BERTECHINI, A.; BRITO, J. Níveis de lisina digestível e seus efeitos sobre o desempenho de poedeiras comercias. In: REUNIÃO DA SOCIEDADE BRASILEIRA DE ZOOTECNIA, 45., 2008, Lavras. Anais... Lavras: Sociedade Brasileira de Zootecnia, 2008. p. 45.

GOULART, C. C. Exigências nutricionais de lisina para poedeiras leves e semipesadas. 1997. Dissertação (Mestrado em Ciência Animal) - Universidade Federal de Viçosa, Viçosa, MG.

HAMILTON, R. P.; FOX, M. R. S.; FRY, B. E.; JONES, A. O. L.; JACOBS, R. M. Zinc interference with copper, iron and manganese in young Japanese quail. Journal of Food Science, Hoboken, v. 44, n. 3, p. 738741, 1979. Available at: <http://onlinelibrary.wiley. com/doi/10.1111/j.1365-2621.1979.tb08488.x/full>. Accessed at: 10 dec. 2016.

HARPER, A. E.; ROGERS, Q. R. Amino acid imbalance. Proceedings of the Nutrition Society, Cambridge, v. 24, n. 2, p. 173-190, 1965. Available at: <https://www. cambridge.org/core/services/aop-cambridge-core/ content/view/S0029665165000344>. Accessed at: 10 dec. 2016.

INSTITUTO BRASILEIRO DE GEOGRAFIA E ESTATÍSTICA - IBGE. Tabelas de Produção da Pecuária Municipal. IBGE, 2014. Disponível em: <ftp://ftp.ibge. gov.br/Producao_Pecuaria/Producao_da_Pecuaria Municipal/2013/ tabelas_pdf/tab22.pdf $>$. Acesso em: 29 ago. 2017.

JARDIM FILHO, R. M.; STRINGHINI, J. H.; ANDRADE, M. A.; CAFÉ, M. B.; LEANDRO, N. S. M.; CARVAlHO, F. B. D. Níveis de lisina digestível para poedeiras Hy-Line W-36 em produção. Revista Brasileira de Zootecnia, Viçosa, MG, v. 39, n. 4, p. 787795, 2010. Disponível em: <http://repositorio. unesp.br/ handle/11449/30827>. Acesso em: 10 dez. 2016.

JORDÃO FILHO, J.; SILVA, J. H. V. da; SILVA, E. L. da; LUIS, M.; RIBEIRO, G.; MARTINS, T. D. D.; RABELLO, C. B. V. Exigência de lisina para poedeiras semipesadas durante o pico de postura. Revista Brasileira de Zootecnia, Viçosa, MG, v. 35, n. 3, p. 1728-1734, 2006. Disponível em: <http://agris.fao.org/agris-search/ search.do?recordID $=$ XS2006280621 $>$. Acesso em: 10 dez. 2016.

LIMA, M. R.; SILVA, J. H. V. Efeito da relação lisina: arginina digestível sobre o desempenho de poedeiras comerciais no período de postura. Revista Acta Veterinária Brasílica, Mossoró, v. 1, n. 4, p. 118-124, 2007. Disponível em: <https://periodicos.ufersa.edu.br/ revistas/index.php/acta/article/view/519>. Acesso em: 10 dez. 2016. 
LIMA, M. R.; VILAR DA SILVA, J. H.; ROCHA, J.; ARAÚJO, J.; ARAÚJO, D.; JORDÃO FILHO, J.; FERNANDES, J. Relações lisina e arginina digestíveis para poedeiras leves e semipesadas no pós-pico de postura. In: REUNIÃO ANUAL DA SOCIEDADE BRASILEIRA DE ZOOTECNIA, 42., 2005, Goiânia. Anais... Goiânia: SBZ, 2005. p. 42.

LLOBET, C. J. A.; PONTES, M. P.; GONZALEZ, F. F. Factores que afectan a la calidad del huevo. In:

Producción de huevos. Barcelona: Technograf SA, 1989. p. 255-274.

MURAKAMI, A. E.; ARIKI, J. Produção de codornas japonesas. Jaboticabal: FUNEP, 1998. v. 507, 79 p.

PASTORE, S. M.; OLIVEIRA, W. P. de; MUNIZ, J. C. L. Panorama da coturnicultura no Brasil. Web Magazine Nutritime, Viçosa, v. 9, n. 6, p. 2041-2049, nov./dez. 2012.

PINTO, R.; FERREIRA, A. S.; DONZELE, J. L.; ALBINO, L. F. T.; SILVA, M. A.; SOARES, R. T. R. N.; PEREIRA, C. A. Exigência de metionina mais cistina para codornas japonesas em postura. Revista Brasileira de Zootecnia, Viçosa, MG, v. 32, n. 5, p. 1166-1173, 2003. Disponível em: <http://www.scielo.br/pdf/\%0D/ rbz/v32n5/17899.pdf>. Acesso em: 10 dez. 2016.

RIBEIRO, C. L. N. Niveis de lisina digestivel em rações. 2011. Tese (Doutorado em Ciência Animal) Universidade Federal de Viçosa, Viçosa, MG.

ROCHA, T. C.; GOMES, P. C.; DONZELE, J. L. Níveis de lisina digestível em rações para poedeiras no período de 24 a 40 semanas de idade. Revista Brasileira de Zootecnia, Viçosa, MG, v. 38, n. 9, p. 1726-1731, 2009. Disponível em: <https://www.researchgate. net/profile/Heloisa_Mello/publication/250040244_ Niveis_de_lisina_digestivel_em_racoes_para_ poedeiras_no periodo_de_24_a_40_semanas_de_idade/ links/5400752b0cf29dd7cb526913/Niveis-de-lisinadigestivel-em-racoes-para-poedeiras-no-periodo-de-24a-40-semanas-de-idade.pdf $>$. Acesso em: 10 dez. 2016.

ROLAND, D. A. Recent developments in egg shell quality. Minneápolis: Feedstuffs, 1976. 31 p.

ROSTAGNO, H. S.; GOMES, P. C.; OLIVEIRA, R. F.; LOPES, D. C.; FERREIRA, A. S.; BARRETO, S. L. T.; EUCLIDES, R. F. Tabelas brasileiras para aves e suinos: composição de alimentos e exigências nutricionais. 3. ed. Viçosa, MG: Universidade Federal de Viçosa, 2011. 259 p.

SÁ, L.; GOMES, P.; ROSTAGNO, H. Exigência de lisina para poedeiras leves no período de 34 a 50 semanas de idade. In: REUNIÃO ANUAL DA SOCIEDADE
BRASILEIRA DE ZOOTECNIA, 40., 2004, Campo Grande. Anais... Campo Grande: Sociedade Brasileira de Zootecnia, 2004. CD-ROM.

SÁ, L. M.; GOMES, P. C.; CECON, P. R.; ROSTAGNO, H. S.; D'AGOSTINI, P. Exigência nutricional de lisina digestível para galinhas poedeiras no período de 34 a 50 semanas de idade. Revista Brasileira de Zootecnia, Viçosa, MG, v. 36, n. 6, p. 1829-1836, 2007. Disponível em: <http://www.sbz.org.br/revista/ artigos/5318.pdf>. Acesso em: 10 dez. 2016.

SAKOMURA, N. K.; ROSTAGNO, H. S. Métodos de pesquisa em nutrição de monogástricos. Jaboticabal: FUNEP, 2007. 283 p.

SCHMIDT, M.; GOMES, P. C.; ROSTAGNO, H. S.; ALBINO, L. F. T.; NUNES, R.; CALDERANO, A. Exigência nutricional de lisina digestível para poedeiras leves no segundo ciclo de produção. Revista Brasileira de Zootecnia, Viçosa, MG, v. 37, n. 6, p. 1029-1035, 2008. Disponível em: <http://www.scielo.br/ pdf/rbz/ v37n6/v37n6a12>. Acesso em: 10 dez. 2016.

SCHMIDT, M.; GOMES, P. C.; ROSTAGNO, H. S.; FERNANDO, L.; ALBINO, T.; NUNES, R. V.; CARVALHO MELLO, H. H. D. Níveis nutricionais de metionina + cistina digestível para poedeiras leves no segundo ciclo de produção. Revista Brasileira de Zootecnia, Viçosa, MG, v. 40, n. 1, p. 142-147, 2011. Disponível em: <http://www.scielo.br/pdf/rbz/v40n1/ v40n1a20>. Acesso em: 10 dez. 2016.

SCHUTTE, J. B.; SMINK, W. Requirement of the laying hen for apparent fecal digestible lysine. Poultry Science, Champaign, v. 77, n. 5, p. 697-701, 1998. Available at: <https://academic.oup.com/ps/article/ 77/5/697/1493916/Requirement-of-the-laying-hen-forapparent-fecal>. Accessed at: $10 \mathrm{dec} .2016$.

SILVA, J. H. V.; COSTA, F. G. P. Tabela para codornas japonesas e europeias. 2. ed. Jaboticabal: FUNEP, 2009. $110 \mathrm{p}$.

SILVA, J. H. V.; JORDÃO FILHO, J.; COSTA, F. G. P.; LACERDA, P. B. de; VARGAS, D. G. V. Exigências nutricionais de codornas. Revista Brasileira de Saúde e Produção Animal, Salvador, v. 13, n. 3, p. 775- 790, 2012.

SILVA, J. H. V.; JORDÃO FILHO, J.; SILVA, E. L.; RIBEIRO, M. L. G. Por que formular dietas para poedeiras com base no conceito de proteína ideal? Revista Ave World, Campinas, v. 3, n. 3, p. 57-65, 2005.

SINGH, R. V.; NARAYAN, R. Produção de codornas nos trópicos. In: SIMPÓSIO INTERNACIONAL DE COTURNICULTURA, 1., 2002, Lavras. Anais... Lavras: Universidade Federal de Lavras, 2002. p. 27-36. 
SOUZA, E. S.; STRINGHINI, J. H.; CARVALHO, F. B. Desempenho de poedeiras alimentadas com diferentes níveis de lisina e arginina digestíveis durante o $1^{\circ}$ pico de produção. In: CONGRESSO DE PESQUISA, ENSINO E EXTENSÃO DA UFG - CONPEEX, 14., 2006, Goiânia. Anais Eletrônicos... oiânia: UFG, 2006. CD-ROM.

UNIVERSIDADE FEDERAL DE VIÇOSA - UFV. SAEG - Sistema para análise estatística e genética. Version 9.1. Viçosa, MG: Arthur Bernardes Foundation, 2007.

WU, G.; BAZER, F. W.; CUDD, T. A.; MEIININGER, C. J.; SPENCER, T. E. Maternal nutrition and fetal development. The Journal of Nutrition, Texas, v. 134, n. 9, p. 2169-2172, 2004. Available at: $<$ http://jn.nutrition.org/content/134/9/2169.full. pdf $\&$ member $=\&$ journal $=$ nutrition $\&$ volume $=134 \& i>$. Accessed at: 10 dec. 2016.
WU, G.; BAZER, F. W.; HU, J.; JOHNSON, G. A.; SPENCER, T. E. Polyamine synthesis from proline in the developing porcine placenta. Biology of Reproduction, Texas, v. 72, n. 4, p. 842-850, 2005. Available at: <https://www.ncbi.nlm.nih.gov/ pubmed/15576824?dopt=Abstract $>$. Accessed at: $10 \mathrm{dec}$. 2016.

WU, G.; MORRIS JUNIOR, S. Arginine metabolism: nitric oxide and beyond. Biochemistry Journal, Portland, v. 336, n. 1 , p. $1-17,1998$. Available at: <http://www. biochemj.org/content/336/1/1>. Accessed at: $10 \mathrm{dec}$. 2016. 